\title{
Midwifery Enterpreneurship Education Influences On Entrepreneurial Motivation Of Students At Sari Mulia Midwifery Academy Banjarmasin
}

\author{
Sitti Khadijah ${ }^{1 *}$ \\ ${ }^{1}$ Academy of Midwifery Sari Mulia, Banjarmasin Indonesia \\ sitti_khadijah@stikessarimulia.ac.id \\ ${ }^{2}$ Monry Fraick Nicky Gillian Ratumbuysang \\ ${ }^{2}$ FKIP Universitas Lambung Mangkurat, Banjarmasin Indonesia \\ monryratumbuysang@gmail.com
}

\begin{abstract}
Objective: This study aims to determine the influence of Midwifery entrepreneurship education on entrepreneurial motivation of students at Sari Mulia Midwifery Academy Banjarmasin

Method: Data collection techniques used were questionnaires given to 76 students of Sari Mulia Midwifery Academy who previously had taken Midwifery entrepreneurship education course.

Results: The results of hypothesis testing shows that Midwifery entrepreneurship education had an effect on entrepreneurial motivation of Sari Mulia Midwifery Academy students, indicated by the R value count of 0,369 and by linear simple regression coefficient result of midwifery entrepreneurship education variable of 0,515 , so then hypothesis of the study is accepted.

Conclusion: There is an influence of Midwifery entrepreneurship education on entrepreneurial motivation of students at Sari Mulia Midwifery Academy Banjarmasin
\end{abstract}

Keywords: Education, Enterpreneurship, Midwifery Students, Motivation.

\section{INTRODUCTION}

The problem of low entrepreneurial interests and motivations from university students currently becomes serious thoughts of many parties in Indonesia such as the government, higher education institutions, industrial parties as well as the community. Various efforts have been done to grow entrepreneurial intentions of university students especially to change their mindset of becoming the job seekers. This is a challenge for higher education institutions as places producing university graduates. Cultivating entrepreneur intentions of students through entrepreneurship education is one of the tasks of Indonesian universities because it is believed to be an alternative way to decrease the number of unemployments, as scholars are expected to be well-educated young entrepreneurs who are able to pioneer their own businesses [1].

Entrepreneurship education is central thing associated with student entrepreneurship. Research findings have shown that the role of college by providing holistic support can help form students' entrepeneurial intentions [2]. 
The government of Indonesia has instructed entrepreneurship education course to be given at college in order to create competent young entrepreneurs with their bachelor degrees who can help reducing the number of unemployments. Entrepreneurship education course is expected to give students knowledge and skills of entrepreneurship when they graduate. For midwifery students, midwifery entrepreneurship education course will give them knowledge to be midwives who are able to establish a private practice clinic and courageously bear the risks to set up legal-body business of midwifery services if they do not get the opportunity to be government employee or civil servant [3].

Becoming a midwife who excelled in the field of entrepreneurship in the form of independent practices and able to create jobs, in particular the entrepreneurship in the field of health will really help tackle unemployment. Entrepreneurship is the mental attitude and the nature of the soul which is always active in trying to advance the work of her devotion in order to increase revenue in her business activities [4].

The midwifery entrepreneurship education course that is presented at the Midwifery Academy is to improve midwifery students' motivations and removes the presumption that entrepreneurship is a very difficult business. In general, this course is also very necessary to strengthen the economy of Indonesia. The midwifery entrepreneurship education course is also expected to bring up the entrepreneurial creative that could create jobs and could help reduce unemployment which is never endless. This course not only gives theoretical foundation of the concept of entrepreneurship but also shapes attitudes, behaviors, and mindset to be an entrepreneur and an independent midwife [5].

The relationship of motivation factors are very closely related to the interests. Motivation factors are related to the onset of a person's interest to take action or achieve her objectives [6]. How one can perceive her decision to create an action is associated as well with the values and motivations. The higher the value of the important goals she wants to accomplish, the more she might take action to achieve those goals [7].

\section{RESEARCH METHOD}

This research was conducted to find out the influence of midwifery entrepreneurship education on entrepreneural motivation of Sari Mulia Midwifery Academy students by using quantitative approach. Research methods used was descriptive and causal research to analyze the relationship between variable $\mathrm{X}$ (Midwifery Entrepreneurial Education course) and variable $\mathrm{Y}$ (entrepreneurial motivation of students) causally. The population of the research was the entire students at Sari Mulia Midwifery Academy who had undergone Midwifery entrepreneurship education course. 
Total sample-taking technique was taken and the questioners were distributed. A total of 76 valid data was collected and adequate as well as justifiable for the intended simple regressions analysis.

\section{RESULTS}

The results of descriptive analysis on research variable of midwifery entrepreneurship education showed that $77.6 \%$ of students understood the contents of the syllabus as a reference study, $80 \%$ felt the material given was in accordance with the contents of the syllabus, $84.2 \%$ of students considered the methods used by the lecturers were in accordance with the material presented, $52.6 \%$ of the students agreed that the delivery of the course always made them paid attention to the lessons, $73.7 \%$ of the students agreed that the method used by the lecturers made them understand the concept of entrepreneurship, $72.3 \%$ of students agreed that the college (Sari Mulia Midwifery Academy) provides infrastructure and facilities for the practice of entrepreneurship, $69.7 \%$ of students assumed that Sari Mulia Midwifery Academy provided budget funds for the students to carry out business visits, $69.7 \%$ of students considered that the college complemented educational facilities to facilitate students' learning about entrepreneurship, $76.3 \%$ of the students were excited to follow midwifery entrepreneur education course and $57.9 \%$ of the students were never ditching the class.
The descriptive analysis on the research variable of entrepreneurial motivation of Sari Mulia Midwifery Academy students showed the results that $53.9 \%$ of students had already started a new business after getting midwifery entrepreneurial education course, $61.8 \%$ of students felt that the entrepreneurial world was no longer a new world for them, $68.4 \%$ of students argued that by doing entrepreneurship they could become rich and successful, $42.1 \%$ of students agreed less that becoming entrepreneurs were more profitable than as employees, $67.1 \%$ of students considered that self-employment was a challenging world and full of experience, $43.4 \%$ of students stated that being entrepreneurs were their goals, $50 \%$ of students stated that they were encouraged to become entrepreneurs by their families, $36.8 \%$ of students were born to a family of entrepreneurs, $71.1 \%$ of students felt that learning midwifery entrepreneurship education made them more motivated to be entrepreneurs and $64.5 \%$ of students loved to read the profile of a successful entrepreneur.

The results of the research by using simple linear regression analysis obtained were presented in Table 1.

Table 1. Simple linear regression analysis result

\begin{tabular}{cccc}
\hline Model & $\mathrm{R}$ & $\mathrm{R}$ Square & $\begin{array}{c}\text { Adjusted R } \\
\text { Square }\end{array}$ \\
\hline 1 & $.369^{\mathrm{a}}$ & .136 & .124 \\
\hline
\end{tabular}

Based on table 1, the partial $r$ of 0,369 was retrieved, which means variable $\mathrm{X}$ (midwifery entrepreneurial education) has a 
positive relationship with variable $\mathrm{Y}$ (students' entrepreneurial motivation) but if it is seen from the result of $\mathrm{r}$, then $r_{\text {count }}$ was situated on a low category.

Table 2. Coefficient of Indepent Variable

\begin{tabular}{lcccc}
\hline \multicolumn{1}{c}{ Model } & $\mathrm{B}$ & Beta & $\mathrm{t}$ & Sig. \\
\hline 1 (constant) & 12.968 & & 2.838 & .006 \\
\hline $\begin{array}{l}\text { Midwifery } \\
\begin{array}{l}\text { Entrepreneurship } \\
\text { Education }\end{array}\end{array}$ & .515 & .369 & 3.411 & .001 \\
\hline
\end{tabular}

Based on table 2, it can be seen that in simple linear regression:

$Y^{\prime}=a+b X$

$\mathrm{Y}^{\prime}=\mathrm{X}+0.51512,968$

the constants of 12,968 means that if variable $\mathrm{X}$ is 0 , then the value of variable $\mathrm{Y}$ is 12,968 . The regression coefficient of variable $\mathrm{X}$ of 0.515 means that, if variable $X$ has an increase of 1 , then variable $\mathrm{Y}$ will have an increase of 0.515 where the value of $\mathrm{Y}$ becomes 12,968 . The coefficient was positive, this means that there was a positive relationship between variable $\mathrm{X}$ (midwifery entrepreneurial education) with variable $\mathrm{Y}$ (students' entrepreneurial motivation).

\section{IV.DISCUSSION}

The research results indicated that from midwifery entrepreneurship education variable, the students of Sari Mulia midwifery Academy understood the syllabus as learning reference, but only $77.6 \%$ of them. According to them, the material that had been taught was appropriate $(80 \%)$. However, the research results on the ways and methods used by lecturers in presenting their materials about entrepreneurship need to be given in a way that could attract students' attention so that they could understand the concepts given. It can be seen from the respondents' answers that only $52.6 \%$ of them agreed that the delivery of the lessons about entrepreneurship always attrack them to pay attention to midwifery entrepreneurship education course. For that case, direct practice can be considered effective in learning about entrepreneurship. Such activities can be executed as long as the facilities and infrastructure are provided. If the students want to hold a business visit, procurement of funds should be prepared.

From the research results on students' entrepreneurial motivation variable, $53,9 \%$ of students had already started businesses after they got midwifery entrepreneurship education course and $61.8 \%$ of them claimed that the entrepreneurial world was not something new for them. $68,4 \%$ of the students at Sari Mulia Midwifery Academy also had a presumption that by doing entrepreneurship, they could be rich and successful. In the entrepreneurial world, challenging job turned out to be liked by most of the students at Sari Mulia Midwifery Academy $(67,1 \%)$. However, despite that they knew the risks in entrepreneurship, the students remained afraid of lossing if they were going to start a business. It was shown 
by $42,1 \%$ of the students disagreed that being entrepreneurs they would be rich and successful.

Being an entrepreneur is actually more profitable than being a clerk, but the students of Sari Mulia Midwifery Academy wanted to be employees more than to become entrepreneurs. It was shown by only a half of them (50\%) were supported to be entrepreneurs by their families. Supports from the parents are very important for students. The supports from the parents for students to be entrepreneurs had increased the entrepreneurial motivations of students as shown by the results of research done by Lestari (2012) which found that students' entrepreneurial interests were also strengthened by demographic factors such as gender, work experience and parents' jobs [8].

The entrepreneurial motivation of the students at Sari Mulia Midwifery Academy also came from outside of themselves (external factors) where most of the students (64.4\%) loved to read profiles of succesful entrepreneurs. This result is in accordance with the research results of Kadarsih (2013) one of which was the perception on the figure of entrepreneurs [9].

Based on the above findings and the results of the statistical analysis, the results of this study stated that there was a positive influence of midwifery entrepreneurship education on entrepreneurial motivation of students at Sari Mulia Midwifery Academy, but it was only $13,6 \%$. The rest, i.e. of $86,4 \%$ was influenced by other factors that were not examined in this study. This result is in accordance with Kourilsky and Walstad (1998) who mentioned that the entrepreneurship education had been considered one of the important factors to foster and develop a passion, soul and behaviour of entrepreneurship among the young generations in particular the college students [1]. The same result of research was also found by Ying Zhang (2014) that stated entrepreneurship education had given a significant positive influence on the interest of students towards entrepreneurship [10]. Another research by Saeid Karimi (2016) also showed that entrepreneurship education programs significantly provided positive influence towards entrepreneurial interest of students [11]. Nevertheless, there are still other factors that can affect students' motivation to be entrepreneurs. Other factors that can affect students' motivation on entrepreneurship can be the need to excel, the family business background and subjective norms [12] as well as self-assurance and the readiness of facilities [13]. To that end, further research is needed to explore further what factors can affect the entrepreneurial motivation of students at Sari Mulia Midwifery Academy. It is also necessary that Sari Mulia Midwifery Academy continually build and drive the ability and interest of their students and graduates to do entrepreneurship 
so that jobs are not a problem for them, because they are able to start their own businesses.

\section{CONCLUSION}

In this study, it can be concluded that midwifery entrepreneurship education influenced the entrepreneurial motivation of students at Sari Mulia Midwifery Academy as shown by partial $r \quad 0,369$ meaning that midwifery entrepreneurship education had a positive relationship with entrepreneurial motivation of students, but was in the low category, which only gave influence of $13.6 \%$. The rest, i.e. of $86.4 \%$, were influenced by other factors that were not examined in this research.

\section{ACKNOWLEDGEMENT}

Credits were given to Sari Mulia Midwifery Academy for giving the permit and became the place for this research.

\section{REFERENCES}

[1]. Pril Ranto D W. Membangun Perilaku Enterpreneur pada mahasiswa melalui Entrepreneurship Education. Maret 2016. JBMA Vol. III, No.1.

[2]. Saadat Saeed, Shumaila Y. Yousafzai, Mirella Yani-De-Soriano, Moreno Muffatto. The Role of Perceived University Support in the Formation of Students' Entrepreneurial Intention.
International Entrepreneurship and Management Journal. Desember 2014, Volume 10, Issue 4, pp 679-689.

[3]. Tando Naomy Marie. Kewirausahaan. 2013. In Media. Yogyakarta

[4]. Priyadi Dimas Audi. Kewirausahaan untuk mahasiswa Kebidanan. 2011. Trans Info Media.

[5]. Arifin Syamsul. Kewirausahaan Kebidanan. 2011. Mitra Wacana Media. Jakarta.

[6]. Aditya Dion Mahesa, Edy Rahardja. Analisis Faktor-Faktor Motivasi yang Mempengaruhi Minat Berwirausaha. Diponegoro Journal of Management. 2012. Volume 1. No.1. Halaman 130137.

[7]. Alain Fayolle, Francisco Linan, Juan A. Moriano. Beyond Entrepreneurial Intentions: values and motivations in Entrepreneurship. International Entrepreneurship and Management Journal. Desember 2014. Volume 10, Issue 4, pp 679-689.

[8]. Lestari R B. Pengaruh pendidikan kewirausahaan terhadap minat berwirausaha mahasiswa di STIE MDP, STMIK MDP dan STIE MUSI. Forum Bisnis dan kewirausahaan Jurnal STIE MDP. 2012. Volume 1 No.2.

[9]. Kadarsih R. Faktor-faktor yang mempengaruhi minat berwirausaha pada mahasiswa program studi pendidikan ekonomi UNS. Jurnal volume 2 No. 1. 2013. 
[10]. Ying Zhang, Geert Duysters, Myriam

Cloodt. The Role of Entrepreneurship

Education as a Predictor on University

Students' Entrepreneurial Intention.

International Entrepreneurship and

Management Journal. September 2014.

Volume 10, Issue 3, pp 623-641.

[11]. Saeid Karimi, harm J.A Biemans,

Thomas Lans, Mohammad Chizari,

Martin Mulder. The Impact of

Entrepreneurship Education: A Study of

Iranian Students Entrepreneurial

Intentions and Oppoortunity

Identification. Journal of Small

Bussiness Management. 2016. Volume

54 , Issue 1
[12]. Xue Fa Tong, David Yoon Kin Tong,

A. Liang Chen Loy. Factors Influencing Entrepreneurial Intention Among Univerity Students. International Journal of Social Sciences and Humanity Studies. 2011. Vol 3, No.1

[13]. Stein Kristiansen, Nurul Indahti. A Entrepreneurial Intention among Indonesian and Norwegian Students. Journal of Enterprising Culture 12, 55. 2004. 